\title{
What Drives Inflation in MENA Countries?
}

\author{
Mohamed Sami Ben Ali \\ Head, Department of Economics, IHEC Business School of Sousse \\ University of Sousse, Tunisia. \\ E-mail: mohamedSami.benali@ihecso.rnu.tn
}

\author{
Sami Ben Mim \\ Faculty of Business and Economics of Mahdia, University of Monastir, Tunisia. \\ E-mail: sbenmim@yahoo.fr
}

Received: January 16, 2011

Accepted: July 5, 2011

doi:10.5539/ijef.v3n4p119

\begin{abstract}
This paper assesses the impact of both monetary and non-monetary determinants of inflation for a sample of 8 MENA countries over the period 1980-2009. We carried out different model estimations to examine the impact of five mainstream variable groups on inflation namely structural, business-cycle-related, openness-related and external and monetary variables. To control for robustness of our results, we used alternative estimation techniques, mainly system GMM. Estimation results report strong evidence on the existence of persistent inflation dynamics in these countries. With regards to the world inflation and nominal effective exchange rate, they produce significant and positive effects on inflation. Our empirical findings also report a negative effect of the output gap on inflation. The effect produced by government spending is however surprisingly negative. A last set of regressions suggests a potential explanation for this result: the effect produced by the output gap reflects the effects of both fiscal and monetary policy on inflation. That is a decrease in government spending over a long period enhances growth, reduces the output gap and generates inflation, whereas an increase in money supply produces inflation by enhancing growth and reducing the output gap.
\end{abstract}

Keywords: Inflation, MENA countries, Monetary and non monetary determinants

\section{Introduction}

Forecasting inflation is of interest to everyone. Economic policy makers forecast inflation as a guide to policy making. Firms use inflation forecasts as one of the key inputs in price-setting and financial projections. Workers use inflation forecasts when negotiating salaries with their employers. Also, the importance given to the goal of price stability can be seen for central banks, which institutionally commit themselves to achieve and maintain stable prices as a primary challenge. Along with this, there is now a growing consensus about the deleterious impact on economic performance and social welfare of high inflation (Fischer, Sahay and Végh, 2002). The question that arises in this regard is why do some monetary authorities still have incentives to inflate? The answer lies mainly on the short-run gains that might be accomplished through loose monetary policies, mainly to finance fiscal deficits or to exploit a negative relationship between unemployment and inflation. Such time inconsistency problems as highlighted by Barro and Gordon (1983) and Kydland and Prescott (1977) arise mostly in countries lacking the required discipline to prevent monetary authorities from focusing on short-run horizons.

Historically, one can see that inflation rates are very different across countries and over time due to various historical country-specific causes. After high inflation and hyperinflation episodes that have characterized the developed and the developing countries in the mid-seventies and eighties (Fischer et al., 2002), the last two decades witnessed a disinflationary process that helped inflation to converge to one digit level in most countries in the world. In developing countries such convergence process began with stabilization programs and reform agendas implemented in the late $80 \mathrm{~s}$ and early $90 \mathrm{~s}$ with the support of the international monetary institutions. These reforms were a part of structural adjustments programs, where weak institutions and economic policy practices were severely questioned and replaced with stronger and consistent ones.

After this long period of relative price stability both in developed and developing countries, inflation has re-emerged around the world as a global challenge with serious socio-economic implications. The MENA region and oil exporting countries are particularly concerned with this trend. While they have until recently enjoyed mild to moderate inflation, theses countries have mostly seen their situations deteriorates rapidly. Boosted by large increases 
in petroleum international prices, oil exporting countries have enjoyed unprecedented levels of liquidity. Conversely, oil importing countries underwent a general rise in domestic prices which in turn fueled the domestic inflationary pressures. In this regard, average inflation for the region have witnessed a sharp increase to double digit levels for certain countries, while for others significant surges were registered.

When dealing with the pace of inflation in our sample of MENA countries there is a need to distinguish heterogeneous paces. Three main clusters can be distinguished in this regard: a mild-to-moderate inflation pace in Morocco, Tunisia, Algeria, Bahrain and Saudi Arabia where inflation generaly does not exceed one digit levels. A second cluster with high pace inflation for UAE and Oman, mainly in recent years, and a third cluster with run-away inflation for Iran which has witnessed the highest and most persistent inflation. Countries in these two later clusters have benefited from exceptionally high petroleum revenues. As a result, both governments and the private sector enjoyed unprecedented levels of liquidity and a strong money supply growth.

Regarding the importance of forecasting inflation determinants for MENA countries, numerous studies have been devoted to such an issue. Except for a few papers (see for example Kandil and Morsy, 2009; Hasan and Alogeel, 2008), most of these studies are, however, confined to country case settings or considered a limited number of inflation determinants (Khemiri and Ben Ali (2011) for Tunisia, Lim and Papi (1997) for Turkey, Bonato (2007) for Iran, and Diouf (2007) for Mali). This paper attempts to fill this gap and to contribute to the empirical literature on the determinants of inflation. To our knowledge, this is the first paper to provide a cross-country empirical analysis of the key driving factors of inflation in 8 Middle Eastern and North African countries. In this regard, we consider in this study broad and comprehensive monetary and non monetary determinants of inflation. We also assembled a large dataset for a 30 year period (1980-2009). This period includes both inflation rising and declining periods.

The rest of the paper is organised as follows: Section 2 provides a concise literature review of the potential determinants of inflation. Section 3 presents the methodology: variables and data used in the study, model specification and econometrics techniques. Section 4 presents the empirical results. Finally, section 5 goes back to the main conclusions of this study and addresses some policy recommendations.

\section{A close look at potential inflation determinants}

When surveying economic literature, a plethora of definitions and theories for the concept of inflation can be found. In this regard, a growing consensus has developed to define inflation with respect to its symptoms as a sustained rise in the economy's aggregate price level. On one hand, when aggregate demand grows faster than the level of aggregate supply, it "pulls" prices higher creating demand-pull inflation. On the other, when firms' costs increase continuously as in the cases of rising wages, interest rates, taxes, imported input prices, or nominal exchange rates fluctuations, inflation is said to be cost-push inflation. Drawing a clear demarcation line between cost-push and demand-pull determinants of inflation is not an easy task as factors driving inflation may interfere. Besides, this traditional distinction has been criticized among economists as being artificial and imprecise since the time path of inflation might include elements of both sides.

When turning from these partially explanatory and interfering theories of inflation to a causal explanation, economic theory suggests several alternative ways of predicting factors which drive inflation, distinguishing five mainstream inflation determinants namely: business-cycle-related, openness-related, external, structural and monetary variables (Calderón and Schmidt-Hebbel, 2008). In this paper, we develop and discuss a framework for analyzing and forecasting inflation based on this strand of literature by trying to combine their main items. The motivation for this kind of analysis is based on the partial explaining power of all these theories: each of them fails to provide a full single cause explanation of inflation on itself (Hendry, 2001 and Metin, 1995). Also, even intuitively, applying a particular theory automatically implies that the set of inflation determinants is restricted to variables representing only this chosen theory. The scope of empirical investigation is then limited, and as inflation dynamics is complex to be described by a single theory, there is a risk of misspecification of the estimated models.

\subsection{Business-cycle-related variables}

Literature on inflation accounts for the oil price and the output gap as cyclical variables. It is obvious that higher oil prices increase inflationary pressures as it influences production costs. Borio and Filardo (2007), in a large cross-section of countries, find that proxies for oil prices add considerable explanatory power to traditional benchmark inflation rate equations. Also, the neo-keynesian framework suggests the existence of a short-run Phillips Curve that relates some measure of economic activity to inflation (Gali 2007, Gali and Gertler 2004). Output gap is the variable that contains valuable information to predict short-run inflationary pressures (Clark and McCracken, 2006).

\subsection{Openness-related variables}

Economic literature accounts for the impact of openness on domestic inflation through both trade and capital account channels. Empirical literature suggests that countries with a more open trade economy have lower inflation 
levels. Two main arguments explain this relationship. First, trade openness comes along with higher foreign competition which makes local firms prone to put extra effort on cost-control. Second, increased competition and integration to world markets can foster productivity growth, which persistently lowers costs (Grossman and Helpman, 1991). Numerous studies support for such negative relationship (Terra, 1998; Gruben and McLeod, 2004; Temple 2002 and Borio and Filardo, 2007). Regarding capital account openness on inflation, two main relationships could be suggested. First, capital account openness is a final stage of a set of improvements of the economic framework including sound monetary policies, fiscal discipline, and central bank independence. Such improvements help reducing inflation (Tytell and Wei, 2004). Second, the theory of optimal taxation suggest that financial integration lowers the cost of foreign financing both for firms and for fiscal deficits, which will likely lower production costs for firms and for governments using seigniorage revenues to finance fiscal deficits. Thus, these consequences will in turn lower inflation (Phelps, 1973).

\subsection{External variables}

There is now a growing body of literature that stresses the predominant effect of world inflation on domestic inflation (Borio and Filardo, 2007). World inflation is supposed to exert a positive effect on domestic inflation through import and export prices. It makes factor prices more expensive to produce exports and it also makes imports more expensive in world markets. However, MENA countries are particularly highly dependent on imports of consumption and intermediate goods, and inflation in major trading partners is likely to create additional inflationary pressures.

\subsection{Structural Variables}

Inflation dynamics can entail accomplishments of some short-run objectives for monetary authorities such as governments' temptations to exploit a negative relationship between unemployment and inflation or monetization of a public deficit. The fiscal theory of inflation suggests that, the more important the government spending, the more likely it is that a country will choose to make use of seigniorage to finance public expenditure beyond tax revenue. Sargent and Wallace (1981), Cukierman (1992), Phelps (1973), Végh (1989). Catao and Terrones (2005) report a positive relationship between fiscal deficits and inflation levels.

In an open economy that interacts to some extent with the rest of the world, external factors may affect domestic inflation as well. Key among these factors is the exchange rate pass-through. In this regard, our analysis considers the inflationary pressures generated by the nominal effective exchange rate variations, capturing movements in bilateral exchange rates with respect to major trading partners. While the peg fixes the exchange rate with respect to the U.S. dollar or a basket of currencies in the considered countries, depreciation in nominal bilateral exchange rates is likely to increase import prices and inflation. The analysis in Lim and Papi (1997) highlights the role of exchange rate pass-through in determining inflation in Turkey. De Brower and Ericsson (1998) model inflation in Australia using a mark-up model. Juselius (1992) investigates spillover effects of German shocks on inflation in Denmark via interest rate and exchange rate channels. Ghavam, Masoodi and Tashkini (2005) also showed that the exchange rate is a significant factor contributing to inflation in Iran.

\subsection{Monetary variables}

Monetary inflation appears when the money supply far exceeds the growth of the domestic product. In line with the monetary approach led by Milton Friedman, who argues that "inflation is always and everywhere a monetary phenomenon", numerous empirical studies considered monetary determinants of inflation. Darrat (1985) finds that accelerating monetary growth leads to higher inflation in Libya, Nigeria and Saudi Arabia. Hofmann (2006) concludes that monetary indicators are still useful in predicting euro area inflation since the start of EMU. Along the same line, Bonato (2007) and Lim and Papi (1997) find a strong relation between money and inflation respectively in Iran and Turkey.

\section{Methodology}

We first define the set of independent variables. We also describe the data used, the model specification and the estimation techniques.

\subsection{Variables and Data Used in the Study}

In this study, we follow the strands of literature above mentioned classifying inflation determinants into five groups: (a) Business cycle-related variables, (b) monetary variables, (c) structural variables, (d) openness-related variables and (e) external variables. The dependent variable is the annual change in the consumer price index.

We use output gap to account for domestic demand-led inflation. Output gap is the variable that contains valuable information to predict short-run inflationary pressures. We use the average of three international spot prices to 
account for oil price (oil index). We included in our specification the general government final spending as a percentage of GDP (government), which reflects the willingness of the government to endure short-run demand in favor of long-run welfare-enhancing policies. Higher government spending is expected to produce higher inflation. To control for inflation generated by exchange rate depreciation, we used nominal effective exchange rates (neer). Theoretically, an increase in the exchange rate should lead to higher inflation. To account for monetary determinants of inflation, we included the broad money growth as percentage of GDP (M2) and credits to private sector in percentage of GDP (credits). These variables are expected to be positively related to inflation. Imported inflation is proxied by world inflation. Exports and imports as percentage of GDP and Chinn and Hiro's (2008) de jure index of financial openness are used as proxies, respectively, for trade and capital account openness (openness, kopenness). All variables were drawn from the IFS-International Monetary Fund and the WDI-World Bank Development Indicators statistics.

Our sample is composed of 8 MENA countries namely Algeria, Bahrain, Iran, Morocco, Oman, Saudi Arabia, Tunisia and the United Arab Emirates. Data covers the period 1980-2009. Because annual data might be subject to business cycle fluctuations, we split the sample into six five-year periods by averaging annual data. We obtained a balanced panel database composed of 8 cross-sections and 6 periods. Panel data presents the merit to handle double dimension data, since it counts for several individuals observed over time. This has the advantage of taking into account the heterogeneity of the individuals, while analyzing their dynamic behaviour over time. To control for individual heterogeneity we may introduce fixed or random effects in the model. We use the Hausman test (Hausman, 1978) to choose among the fixed effects and the random effects specification.

We briefly describe some statistical properties of the data, focusing primarily on the characteristics of our variables. Table 1 provides the descriptive statistics for the overall sample, while Table 2 presents the correlation matrix for the variables used in this study. Correlation analysis is important since high correlation may induce a colinearity problem and lead to biased results. Therefore, in our estimations we were especially careful when including all variables at the same time, checking for the robustness of the included variables.

Results reported in Table 1 provide evidence for relative high volatility of inflation. So is the case for most independent variables. Inflation rates range from 26, 77\% in Iran between 1995 to 1999 to $-1,72 \%$ in Oman between 1985 to 1989. The standard deviation is higher than mean inflation over the sample period. So is the case for nominal effective exchange rate and output gap. For world inflation, oil price index and capital openness, the standard deviation is largely above $50 \%$ of the mean value for each variable.

As reported in Table 2, inflation is, as expected, negatively correlated to trade and capital openness $(-0,45$ and $-0,487$ respectively) and positively correlated to nominal effective exchange rate $(0,405)$. However, in contradiction with literature, inflation is negatively correlated to credits to private sector $(-0,284)$ and government spending $(-0,495)$. Concerning monetary policy and openness indicators, we noticed that the liquidity ratio (M2) and credits to private sector are strongly and positively correlated $(0,581)$, and so is the case for trade and capital openness $(0,669)$. These findings suggest that we should choose one variable among each pair.

\subsection{Model Specification and Estimation Techniques}

Our empirical framework considers, as discussed above, five mainstream variables. To examine the effect of these variables on inflation in our sample countries, we estimate a linear regression model in the following form:

$$
\text { Infl }_{i, t}=\alpha_{1}+\alpha_{2} X_{i, t}+\mu_{i}+\varepsilon_{i, t}
$$

where Infl $_{i t}$ denotes the inflation rate, $X_{i t}$ is a matrix including the control variables above mentioned, $\mu_{i}$ is a country-specific effect and $\varepsilon_{i, t}$ is the error term.

We first ran OLS regressions without including any country or period specific effect. Estimations will probably lead to biased results for several reasons. For instance, the existence of country and time specific effects, measurement errors and simultaneity problems may all generate estimation bias.

In a second set of regressions, we include country and period specific effects. Controlling for specific effects may eliminate one source of estimation bias. However, our model includes two variables that are constant among all countries: oil price index and world inflation. The presence of time fixed effects along with these variables in the same model will lead to a colinearity problem. The model will therefore include only country specific effects. Moreover, the random effects specification cannot be estimated when all independent variables are included in the model. ${ }^{1}$ In this case, regressions will be limited to country fixed effects. Comparing OLS and fixed effects estimates will be a first step towards distinguishing main inflation determinants.

The final set of regressions is run using System Generalized Method of Moments (SGMM), following Arellano and Bover (1995). This method corrects for measurement errors and simultaneity problems by using internal instruments 
(lagged independent variables) and by combining a level and first-difference specifications of model (1). Measurement errors concern variables like trade and financial openness and the output gap. Simultaneity concerns the nominal effective exchange rate, which can be influenced by large inflation variations. It is also the case for monetary policy indicators, M2 and credits to private sector. An increase in liquid liabilities may cause inflation, but high inflation may also lead central banks to increase money supply.

\section{Results and discussion}

The regression results are shown in Table 3. The first column reports the OLS estimation outcomes without country specific effects. As expected, world inflation and nominal exchange rate produce significant positive effects, whereas output gap produces a negative effect on inflation. Surprisingly, the liquidity ratio, M2, and government spending have negative effects on inflation. The output gap and government spending are the most influential independent variables on inflation: a one percent increase in output gap and government spending produces respectively a $0,479 \%$ and $0,841 \%$ decrease in inflation. According to results in table 3 , trade openness and M2 seem to be the most relevant indicators for monetary policy and openness. Along with this idea, we excluded capital openness and credits to private sector and estimated the model. Results are reported in column 2. The difference with the first estimation output is that trade openness now produces a negative and significant effect on inflation $(-0,038)$. These results suggest that a better specification is the one that includes only M2 and trade openness as indicators for monetary policy and openness respectively.

Similar conclusions may be driven from the country fixed effects models reported in columns 3 and 4. Capital openness and credits to private sector are not relevant independent variables. World inflation and output gap produce respectively positive and negative significant effects on inflation. Finally, government spending effect on inflation is again negative. When capital openness and credits to private sector are excluded from the model, government spending effects become more important, with a one percent decrease in government spending leading to $1,03 \%$ increase in inflation.

The last column shows country random effects specification with only seven independent variables. The Hausman test results show that the random effects model is the best specification in this case. Results are identical to those obtained using OLS. All variables produce significant effects on inflation except the oil price index. Coefficients of independent variables confirm our theoretical expectations, except for M2 and government spending which affect inflation negatively.

The empirical result of this first set of regressions supports the following main findings. First, credits to private sector and capital openness do not produce any significant effect on inflation dynamics. This result is not surprising regarding the high correlation between M2 and credits to private sector. We should also mention that the capital openness indicator exhibits very weak variability within each cross-section which limits its relevance for time series estimations. The second important conclusion is that world inflation, output gap and government spending seem to be the most relevant independent variables, with a surprising negative effect for government spending.

To get further support for these conclusions and to test the robustness of our results, the final set of regressions is run using Generalized Method of Moments regressions System (SGMM). As mentioned above, this method corrects for measurement errors and simultaneity problems.

We included lagged inflation among the independent variables to control for persistent inflation dynamics. The SGMM transformation is applied to the following model:

$$
\operatorname{Infl}_{i, t}=\alpha_{0}+\alpha_{1} \operatorname{Infl}_{i, t-1}+\alpha_{2} X_{i, t}+\mu_{i}+\varepsilon_{i, t}
$$

Second and higher order lags of the independent variables are valid instruments in the presence of lagged dependent variables on the right hand side of the equation. The estimation results obtained using SGMM are reported in table 4.

We first estimated the model including seven independent variables (column 1). Estimation outcomes provide support for the existence of persistent inflation dynamics as lagged inflation produces an important and significant positive effect on present inflation: a one percent increase of past inflation would lead to a $0,52 \%$ increase in current inflation. As expected, world inflation produces a significant and positive effect $(0,30)$, suggesting that inflation is not exclusively explained by domestic factors. Our results also report an important negative effect of output gap on inflation $(-0,45)$. This suggests that an increase in the output gap releases pressure on the supply side and weakens inflation.

The most significant and important effect is the one produced by government spending. Surprisingly, this effect has always been negative and significant for all the regressions we have run until now. According to theory, government spending potentially leads to an increase in money supply, especially in countries with relatively narrow financial 
markets. This may not be the case for most of the countries of our sample. Six out of eight countries in the sample are classified among the most important oil exporters. These countries generally do not face any difficulty financing their government spending. Moreover, countries like Saudi Arabia and the Unites Arab Emirates enjoy high government spending, but never had government debt for almost all of the sample period due to high petroleum revenues. These arguments suggest that, for most of the countries in the sample, government spending does not fuel inflation, but they still do not explain the surprising negative effect.

When testing for the existence of a potential channel through which government spending may affect inflation, output gap is likely to be involved. According to supply side economists, reducing government spending may have positive long run effects on growth. Enhancing growth reduces the output gap and creates inflation. To test the validity of this channel, we ran a set of four regressions. We first eliminated government spending from the set of the control variables (column 2). Estimation outcome shows that the effect of the output gap on inflation is no longer significant, suggesting that the output gap effect is a result of government spending variations. To confirm such a conclusion, we eliminated the output gap from the set of independent variables (column 3). Estimation outcomes show that not only the government spending coefficient is still significant, but the liquidity ratio, M2, produces a positive and significant effect on inflation: a one percent increase of M2 leads to a $0,12 \%$ increase in inflation. This suggests that, in addition to the government spending effect, the output gap also embeds the effect of money supply on inflation.

To get further evidence for these conclusions we introduced the two composite following variables, "govenment $\times$ output gap" and "M $2 \times$ output gap", that test respectively for the interaction between the output gap on one hand and government spending and money supply on the other hand. Results are reported in columns 4 and 5 . Estimation results show that both interaction variables are negative and significant at the $10 \%$ percent level $(-0,016$ and $-0,007$ respectively for the first and the second interaction variables). These results offer robust supports to suggest that the effect produced by the output gap reflects the effects of fiscal and monetary policy on inflation. A decrease in government spending over a long period should enhance growth, reduce the output gap and generate inflation, whereas an increase in money supply should produce inflation by enhancing growth and reducing the output gap.

To get more evidence in this direction, we analyzed the dynamics of these variables for each country separately. Figure 1 plots such trends. At first glance, except for Morocco, government spending graphs shows a negative trend from the mid-eighties for all the other countries in the sample. Positive trends can also be clearly identified for M2, except for Algeria and Iran. Since graphical analysis does not lead to a robust conclusion, we ran Kwiatkowski, Phillips, Schmidt, and Shin (KPSS, 1992) unit root test including a constant and a trend for government spending and liquidity ratio of each country. Tables 5 reports estimation results.

Results offer strong evidence for the negative and positive trends described above. As far as government spending is concerned, seven countries exhibit negative significant trends. Morocco is the only country where government spending is still increasing. Six countries out of eight show strong positive significant trends for M2. Algeria and Iran are the only countries with negative trends for M2. These results provide further support to our conclusions concerning channels through which these two variables affect inflation. This indicates that government spending was decreasing in most countries over the sample period, which fostered growth, reduced the output gap and produced inflation. Through the same channel, increasing liquidity enhanced growth and produced inflation.

\section{Conclusion and policy recommendations}

Forecasting inflation is of interest to everyone: economic policy makers, firms, and workers decision taking processes are based on inflation forecasts. Also, fighting inflation is a primary challenge for any central bank committed to a price stability objective. Along with this, there is now a growing consensus about the deleterious impact on economic performance and social welfare of high inflation.

This paper assesses the impact of monetary and non-monetary determinants of inflation for a sample of 8 MENA countries over the period 1980-2009. We carried out different model estimations to examine the impact of five mainstream variable groups on inflation namely structural, business-cycle-related, openness-related, external and monetary variables. To control for robustness of our results, we used alternative estimation techniques. The empirical findings confirm the existence of a strong evidence for a persistent inflation dynamics as lagged inflation produced an important and significant positive effect on present inflation. Moreover, world inflation and nominal effective exchange rates produce a significant and positive effect on inflation. Our results also report a negative effect of output gap on inflation. This suggests that an increase in the output gap releases pressure on the supply side and weakens inflation. The most significant and important effect is the one produced by government spending. Surprisingly, this effect has always been negative and significant for all the regressions. A central finding of this 
study is that the effect produced by the output gap reflects the effects of fiscal and monetary policy on inflation. That is, a decrease in government spending over a long period should enhance growth, reduce the output gap and generate inflation, whereas an increase in money supply should produce inflation by enhancing growth and reducing the output gap.

Drawing on the empirical research, MENA countries should pursue sound fiscal and monetary policies. To be effective, there is a particular need of curbing governments' spending.

\section{References}

Aisen, A., and Veiga, F.J. (2006). Does Political Instability Lead to Higher Inflation? A Panel Data Analysis. Journal of Money Credit and Banking, 38(5): 1379-1390. doi:10.1353/mcb.2006.0064, http://dx.doi.org/10.1353/mcb.2006.0064

Arellano, M. and Bover, O. (1995). Another Look at the Instrumental-Variable Estimation of Error-Components Models. Journal of Econometrics, No. 68, pp. 29-52. doi:10.1016/0304-4076(94)01642-D, http://dx.doi.org/10.1016/0304-4076(94)01642-D

Barro, R.J. and D. Gordon (1983). Rules, Discretion and Reputation in a Model of Monetary Policy. Journal of Monetary Economics, 12(1), 101-21. doi:10.1016/0304-3932(83)90051-X, http://dx.doi.org/10.1016/0304-3932(83)90051-X

Bonato, L. (2007). Money and Inflation in the Islamic Republic of Iran. IMF Working Paper, 07/119, (Washington: International Monetary Fund).

Borio, C.E.V., and Filardo, A. (2007). Globalisation and Inflation: New cross-country evidence on the global determinants of domestic inflation. BIS Working Papers, No 227, May.

Calderón, C. and Schmidt-Hebbel, K. (2008). What Drives Inflation in the World? Central Bank of Chile Working Papers, $n^{\circ} 491$.

Catão, L. A.V., and Marco E. T. (2005). Fiscal Deficits and Inflation. Journal of Monetary Economics 52(3), pp. 529-554. doi:10.1016/j.jmoneco.2004.06.003, http://dx.doi.org/10.1016/j.jmoneco.2004.06.003

Chinn, M. D. and Hiro I. (2008). A New Measure of Financial Openness. Journal of Comparative Policy Analysis, Volume 10, Issue 3, p. 309 - 322. doi:10.1080/13876980802231123, http://dx.doi.org/10.1080/13876980802231123

Clark, T.E., and McCracken, M.W. (2006). The Predictive Content of the Output Gap for Inflation: Resolving In-Sample and Out-of-Sample Evidence. Journal of Money, Credit, and Banking 38(5), 1127-1148. doi:10.1353/mcb.2006.0068, http://dx.doi.org/10.1353/mcb.2006.0068

Cukierman, A. (1992). Central Bank Strategy, Credibility, and Independence: Theory and Evidence. The MIT Press. Cambridge, Massachussets.

Darrat, A. F. (1986). The demand for money in some major OPEC members: Regression estimates and stability results. Applied Economics 18, pp. 127-142. doi:10.1080/00036848600000019, http://dx.doi.org/10.1080/00036848600000019

De Brouwer, G. and Ericsson, N. (1998). Modeling Inflation in Australia. Journal of Business and Economic Statistics, Vol. 16, pp. 433-49. doi:10.2307/1392612, http://dx.doi.org/10.2307/1392612

Diouf, M. (2007). Modeling Inflation for Mali. IMF Working Paper 07/295, (Washington: International Monetary Fund).

Dollar, D. and Kraay, A. (2003). Institutions, trade and growth. Journal of Monetary Economics, 50 (1): $133-62$. doi:10.1016/S0304-3932(02)00206-4, http://dx.doi.org/10.1016/S0304-3932(02)00206-4

Fischer, S. Sahay, and R., Végh, C., (2002). Modern hyper-and high inflations. Journal of Economic Literature 40(3), 837-80. doi:10.1257/002205102760273805, http://dx.doi.org/10.1257/002205102760273805

Galí, J. (2007). Monetary Policy, Inflation and the Business Cycle: An Introduction to the New Keynesian Framework. Princeton University Press.

Galí, J., and Gertler, M. (1999). Inflation dynamics: A structural econometric analysis. Journal of Monetary Economics, 44(2), 195-222. http://dx.doi.org/10.1016/S0304-3932(99)00023-9

Ghavam M. Z., and Tashkini, A. (2005). Experimental analysis of inflation in Iranian economy, Iranian Journal of Trade studies, 9(36).

Grossman, G.M. and Helpman, E. (1991). Trade, Knowledge Spillovers and Growth. NBER Working Paper, 3485 
Gruben,W. and McLeod, D. (2004). The openness-inflation puzzle revisited. Applied Economic Letters, 11: 465-68. doi:10.1080/1350485042000244477, http://dx.doi.org/10.1080/1350485042000244477

Hausman, J. A. (1978). Specification tests in econometrics. Econometrica, 46 (2): 1251-1271. doi:10.2307/1913827, http://dx.doi.org/10.2307/1913827

Hendry, D. F. (2001). Modelling UK Inflation, 1875-1991. Journal of Applied Econometrics, Vol. 16, 255-275. doi:10.1002/jae.615, http://dx.doi.org/10.1002/jae.615

Hofmann, Boris. (2006). Do Monetary Indicators (Still) Predict Euro Area Inflation? Deutsche Bundesbank Discussion Paper, 18/2006.

Juselius, K. (1994). On the Duality Between Long-Run Relations and Common trends in the I(1) versus I(2) Model: An Application to Aggregate Money Holding. Econometric Reviews, Vol. 13(2), pp. 151-78. doi:10.1080/07474939408800282, http://dx.doi.org/10.1080/07474939408800282

Kandil, M and Morsy, H. (2009). Determinants of Inflation in GCC. IMF Working papers, $n^{\circ} \mathrm{WP} / 09 / 82$.

Khemiri, R. and Ben Ali, M. S. (2011). Exchange Rate Pass-Through and Inflation Dynamic in Tunisia: A Markov Switching approach, Review of Middle East Economics and Finance, forthcoming.

Kydland, F.W. and Prescott, E. (1977). Rules rather than discretion: the inconsistency of optimal plans. Journal of Political Economy, 85(3). 473-91. doi:10.1086/260580, http://dx.doi.org/10.1086/260580

Kwiatkowski, D., Phillips, P. C. B., Schmidt, P. and Shin, Y. (1992). Testing the null hypothesis of stationarity against the alternative of a unit root: How sure are we that economic time series have a unit root? Journal of Econometrics, 54, 159-178. doi:10.1016/0304-4076(92)90104-Y, http://dx.doi.org/10.1016/0304-4076(92)90104-Y

Lim, C. H., and Papi, L. (1997). An Econometric Analysis of the Determinants of Inflation in Turkey. IMF Working Paper, 97/170 (Washington: International Monetary Fund).

Metin, K. (1995). An Integrated Analysis of Turkish Inflation. Oxford Bulletin of Economics and Statistics, 57 (4), : $513-531$.

Phelps, E. (1973). Inflation in the Theory of Public Finance. Swedish Journal of Economics 75, 67-82. doi:10.2307/3439275, http://dx.doi.org/10.2307/3439275

Sargent, T. and Wallace, N. (1981). Some unpleasant monetarist arithmetic. Federal Reserve Bank of Minneapolis Quarterly Review, 5, 1-17

Temple, J. (2002). Openness, Inflation and the Phillips Curve: A Puzzle. Journal of Money Credit and Banking, 34(2), 450-468. doi:10.1353/mcb.2002.0049, http://dx.doi.org/10.1353/mcb.2002.0049

Terra, C.T. (1998). Openness and Inflation: A New Assessment. The Quarterly Journal of Economics, 113(2), 641-648. doi:10.1162/003355398555603, http://dx.doi.org/10.1162/003355398555603

Tytell, I. and Wei, S. (2004). Does Financial Globalization Induce Better Macroeconomic Policies? IMF Working Paper, No. 04/84.

Végh, C., (1989). Government Spending and Inflationary Finance: A Public Finance Approach. IMF Staff Papers 36, 657-77.

\section{Notes}

Note 1. To test for random effects, the number of coefficients to be estimated should be less than the number of cross sections.

Table 1. Descriptive statistics

\begin{tabular}{|c|c|c|c|c|c|c|c|c|c|c|}
\hline & INFL & $\begin{array}{l}\text { WORLD } \\
\text { INFL. }\end{array}$ & $\begin{array}{l}\text { OIL } \\
\text { INDEX }\end{array}$ & NEER & $\begin{array}{l}\text { OUTPUT } \\
\text { GAP }\end{array}$ & M2 & CREDIT & OPENNESS & KOPENNESS & GOVERNMENT \\
\hline Mean & 6.565822 & 12.53667 & 181.8460 & 298.3759 & -0.042073 & 49.36270 & 44.53156 & 88.73042 & 0.553724 & 18.72143 \\
\hline Median & 3.786175 & 11.16000 & 138.5100 & 97.43500 & 0.211987 & 48.82140 & 45.04429 & 78.26412 & 0.567928 & 17.16386 \\
\hline Maximum & 26.77588 & 29.24000 & 418.2460 & 5048.850 & 4.608706 & 93.92337 & 95.51285 & 219.2419 & 1.000000 & 33.26386 \\
\hline Minimum & -1.729977 & 3.720000 & 102.1880 & 67.68200 & -8.778245 & 19.28107 & 4.884723 & 20.67685 & 0.000000 & 10.49811 \\
\hline Std. Dev. & 7.124867 & 8.964356 & 111.6492 & 784.8905 & 2.563964 & 15.60462 & 18.97836 & 44.09931 & 0.415441 & 4.980309 \\
\hline Observations & 48 & 48 & 48 & 48 & 48 & 48 & 48 & 48 & 48 & 48 \\
\hline
\end{tabular}


Table 2. Correlation matrix

\begin{tabular}{|c|c|c|c|c|c|c|c|c|c|c|}
\hline & INFL & $\begin{array}{l}\text { WORLD } \\
\text { INFL. }\end{array}$ & OIL INDEX & NEER & $\begin{array}{l}\text { OUTPUT } \\
\text { GAP }\end{array}$ & M2 & CREDIT & OPENNESS & KOPENNESS & GOVERNMENT \\
\hline INFL & 1.000 & & & & & & & & & \\
\hline WORLD INFL. & 0.079 & 1.000 & & & & & & & & \\
\hline OIL INDEX & 0.086 & $-0.520 * * *$ & 1.000 & & & & & & & \\
\hline NEER & $0.405^{* * *}$ & 0.102 & -0.064 & 1.000 & & & & & & \\
\hline M2 & -0.218 & -0.156 & 0.171 & 0.064 & -0.122 & 1.000 & & & & \\
\hline CREDIT & $-0.284 *$ & -0.171 & $0.244 *$ & -0.053 & 0.006 & $0.581 * * *$ & 1.000 & & & \\
\hline OPENNESS & $-0.450 * * *$ & -0.083 & 0.172 & $-0.309^{* *}$ & 0.096 & $0.274 * *$ & $0.361^{* *}$ & 1.000 & & \\
\hline KOPENNESS & $-0.487 * * *$ & 0.029 & 0.016 & $-0.293 * *$ & -0.014 & -0.149 & 0.137 & $0.669^{* * *}$ & 1.000 & \\
\hline GOVERNMENT & $-0.495^{* * *}$ & $0.244^{*}$ & $-0.345^{*}$ & -0.038 & -0.155 & -0.209 & -0.002 & 0.028 & $0.524 * * *$ & 1.000 \\
\hline
\end{tabular}

Note: $* * *$ significant at 1 percent; $* *$ significant at 5 percent; $*$ significant at 10 percent.

Table 3. Model (1) estimation outcomes

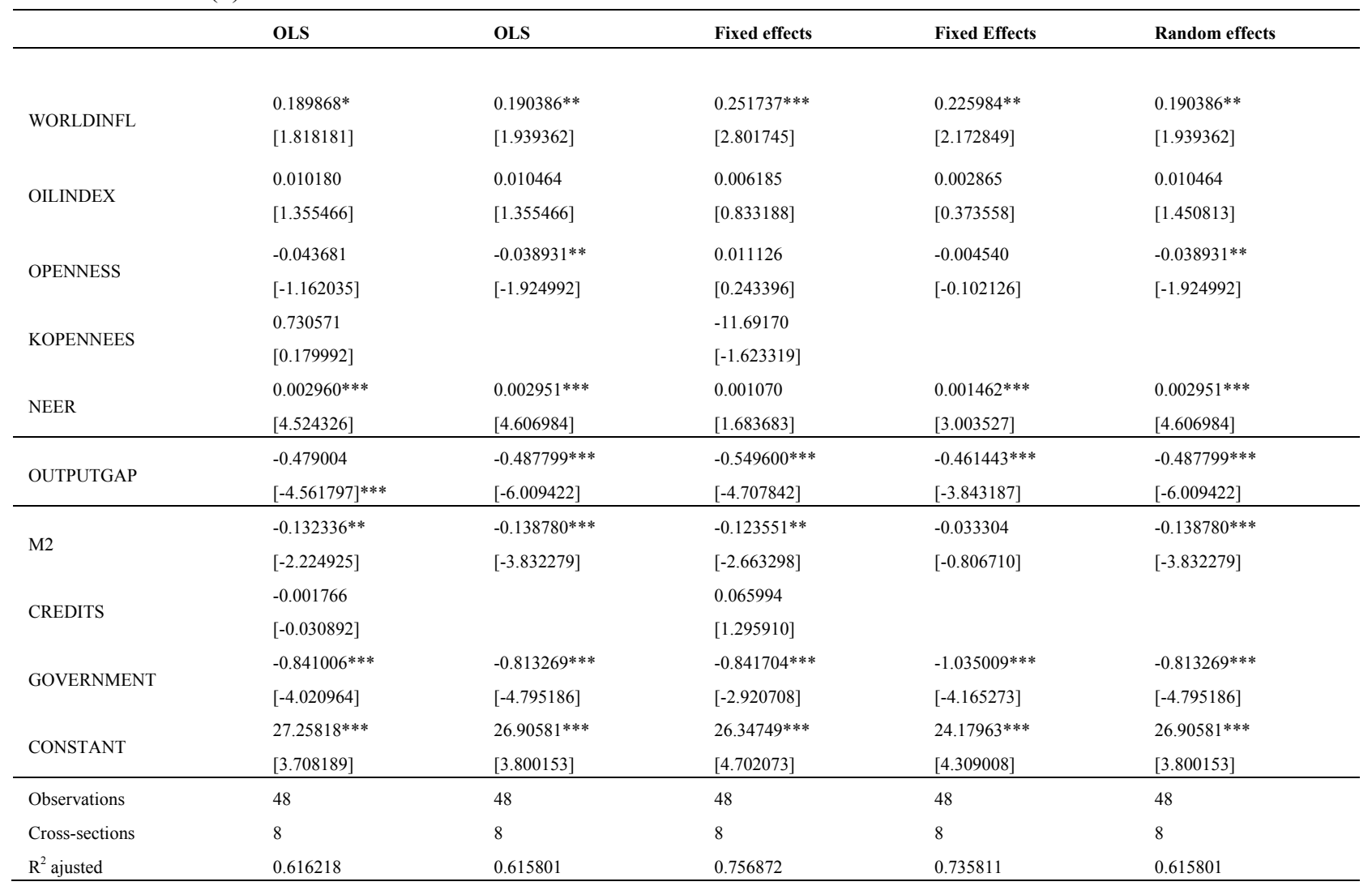

Note: $* * *$ significant at 1 percent; $* *$ significant at 5 percent; $*$ significant at 10 percent; Robust standard errors in parentheses. 
Table 4. SGMM estimation results: dependent variable inflation

\begin{tabular}{|c|c|c|c|c|c|}
\hline \multirow{2}{*}{$\operatorname{INFL}(-1)$} & $0.529888 * *$ & $0.516405^{* *}$ & $0.507601 * * *$ & $0.530536^{* *}$ & $0.537036^{* *}$ \\
\hline & [2.347759] & {$[2.561785]$} & {$[3.374823]$} & [2.368092] & [2.348325] \\
\hline \multirow{2}{*}{ WORLD INFL } & $0.305001^{*}$ & 0.237764 & 0.172820 & $0.284859^{*}$ & $0.298651^{* *}$ \\
\hline & {$[1.780851]$} & {$[1.631301]$} & {$[1.093475]$} & {$[1.725980]$} & {$[1.745057]$} \\
\hline \multirow{2}{*}{ OIL INDEX } & 0.002901 & 0.004855 & $0.022287^{* *}$ & 0.002849 & 0.002971 \\
\hline & {$[0.407763]$} & {$[0.796222]$} & {$[2.326113]$} & {$[0.408003]$} & {$[0.428770]$} \\
\hline \multirow{2}{*}{ OPENNESS } & -0.020769 & -0.058013 & -0.059031 & -0.031128 & -0.023307 \\
\hline & {$[-0.288728]$} & {$[-0.924054]$} & {$[-0.709946]$} & {$[-0.452901]$} & {$[-0.321032]$} \\
\hline \multirow{2}{*}{ NEER } & -0.000365 & 0.000129 & 0.001524 & $-8.56 \mathrm{E}-05$ & -0.000206 \\
\hline & {$[-0.213163]$} & [0.090091] & {$[0.627167]$} & {$[-0.054002]$} & {$[-0.122416]$} \\
\hline \multirow{2}{*}{ M2 } & 0.149941 & $0.122564^{*}$ & -0.015194 & 0.141714 & 0.151634 \\
\hline & {$[1.577078]$} & {$[1.772834]$} & {$[-0.168464]$} & {$[1.586508]$} & {$[1.528364]$} \\
\hline \multirow{2}{*}{ OUTPUT GAP } & $-0.45174 * *$ & & -0.016724 & & \\
\hline & {$[-2.079066]$} & & {$[-0.067986]$} & & \\
\hline \multirow{2}{*}{ GOVERNMENT } & $-1.2579 * * *$ & $-1.0367^{* * *}$ & & $-1.2264^{* * *}$ & $-1.2569^{* * *}$ \\
\hline & {$[-3.850012]$} & {$[-3.128013]$} & & {$[-3.727741]$} & {$[-3.408732]$} \\
\hline \multirow{2}{*}{ GOVERNMENT*OUTPUT GAP } & & & & $-0.016331^{*}$ & \\
\hline & & & & [-1.980902] & \\
\hline \multirow{2}{*}{ M2*OUTPUT GAP } & & & & & $-0.007576^{*}$ \\
\hline & & & & & {$[-1.752262]$} \\
\hline Observations & 32 & 32 & 32 & 32 & 32 \\
\hline \multirow{2}{*}{ Cross-sections } & 8 & 8 & 8 & 8 & 8 \\
\hline & 9401062 & 7.951905 & 9 & 8.726527 & 8.978838 \\
\hline $\begin{array}{l}\text { Sargan stat. } \\
\text { Prob. Sargan }\end{array}$ & 0.401002 & 0,539000 & 0.140123 & 0,462891 & 0,439229 \\
\hline
\end{tabular}

Note: *** significant at 1 percent; ** significant at 5 percent; * significant at 10 percent; Robust standard errors in parentheses.

Table 5. KPSS Unit root tests

\begin{tabular}{|c|c|c|}
\hline & $\begin{array}{l}\text { Trend } \\
\text { Government consumption }\end{array}$ & $\begin{array}{l}\text { Trend } \\
\mathrm{M} 2 / \mathrm{GDP}\end{array}$ \\
\hline Algeria & $\begin{array}{l}-0.158054 * * * \\
{[-4.189828]}\end{array}$ & $\begin{array}{l}-0.831299 * * * \\
{[-2.880066]}\end{array}$ \\
\hline Bahrain & $\begin{array}{l}-0.193216^{* *} \\
{[-2.528052]}\end{array}$ & $\begin{array}{l}0.684226 * * * \\
{[3.946222]}\end{array}$ \\
\hline Iran & $\begin{array}{c}-0.262722^{* * *} \\
{[-6.125469]}\end{array}$ & $\begin{array}{r}-0.688697 * * * \\
{[-3.966675]}\end{array}$ \\
\hline Morocco & $\begin{array}{l}0.049710^{*} \\
{[1.906314]}\end{array}$ & $\begin{array}{l}2.123424 * * * \\
{[21.97255]}\end{array}$ \\
\hline Oman & $\begin{array}{l}-0.351512^{* * *} \\
{[-6.371873]}\end{array}$ & $\begin{array}{l}0.454591 * * * \\
{[5.036695]}\end{array}$ \\
\hline Saudi Arabia & $\begin{array}{c}-0.182290 * \\
{[-1.932342]}\end{array}$ & $\begin{array}{l}0.909831 * * * \\
{[5.152070]}\end{array}$ \\
\hline Tunisia & $\begin{array}{l}-0.071732^{* * *} \\
{[-4.132853]}\end{array}$ & $\begin{array}{l}0.701851^{* * *} \\
{[11.18160]}\end{array}$ \\
\hline United Arab Emirates & $\begin{array}{l}-0.272288^{* * *} \\
{[-4.913810]}\end{array}$ & $\begin{array}{l}1.044296^{* * *} \\
{[5.032805]}\end{array}$ \\
\hline
\end{tabular}

Note: *** significant at 1 percent; ** significant at 5 percent; * significant at 10 percent; Robust standard errors in parentheses. 


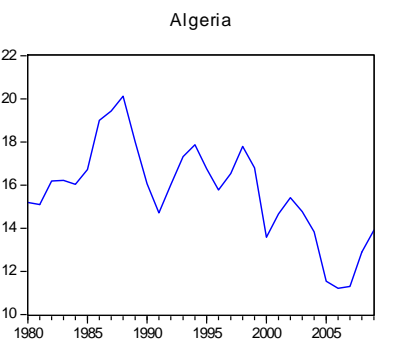

Government spending to GDP
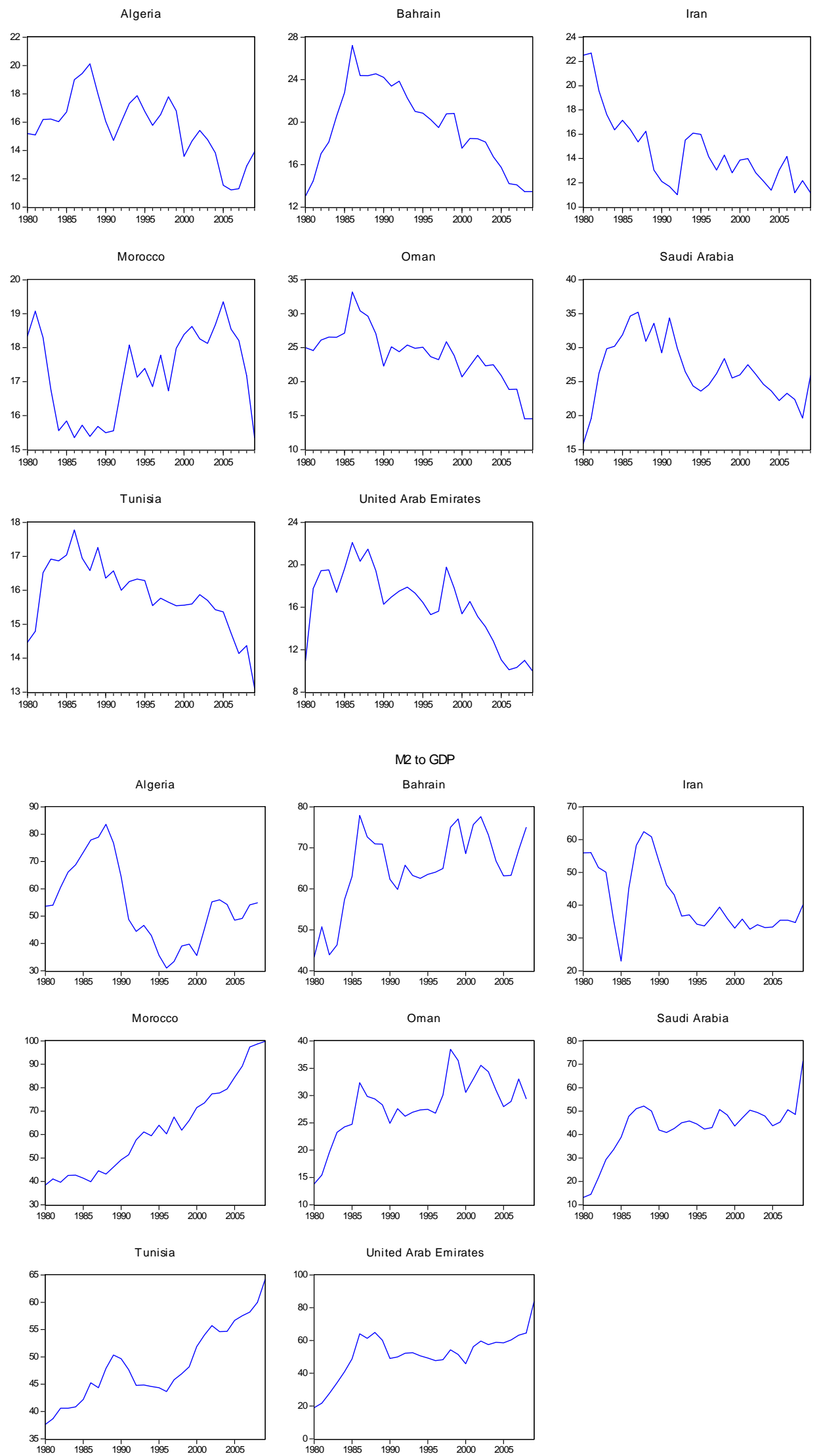

Figure 1. Government spending and M2 